\title{
Exploring the role of the church as a 'reformation agency' in enhancing a socially transformative agenda in South Africa
}

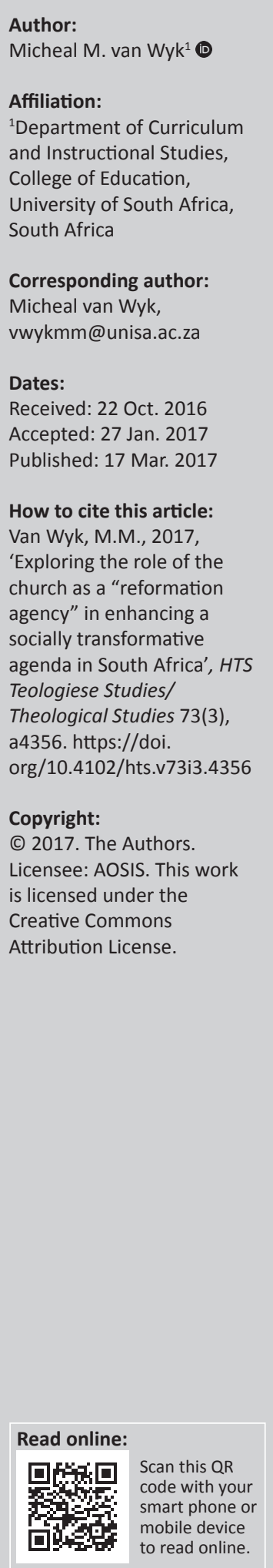

International political, social, economic and religious developments influence how local communities operate. The South African church society is influenced by such developments taking place globally and which clearly influence how local churches function. This article explores the role of the contemporary church as a 'reformation agency' in enhancing a socially transformative agenda in South Africa. A qualitative research approach - an interpretative phenomenology design - was employed to negotiate a shared understanding through conversation and intersubjective meaning-making with church ministers, with the primary focus being their subjective experience of the changing role of the church in enhancing a transformative agenda in a South African context. A purposive sampling $(n=6)$ consisted of local church leaders who participated in the face-to-face and telephonic semi-structured interviews to achieve the purpose of the study. The findings clearly show that deliberate and intentional actions by churches allow them to become a voice for the marginalised, to create spaces for searching for excellence and to increase the quality of servant leadership, all as vehicles for transforming church society. Furthermore, servant leadership is a social phenomenon, a philosophy-in-practice aimed at leading by example to achieve a common goal. To accomplish this, church ministers are required to spearhead the challenge as a prerequisite to creating 'lived experienced' opportunities for members as an inward-outward spiritual journey. Finally, church leaders believed that transformation is a secular dimension, but that it can also be aligned towards God's redemption plan and enhancing a socially just transformation agenda. Ultimately, this study proposed several recommendations to allow the local church to be relevant in practicing and promoting stronger unity and reconciliation amongst all churches nationally and globally.

\section{Introduction}

International political, social, economic and religious developments influence how local communities operate. The South African church society is influenced by such developments taking place globally and which clearly influence how local churches function. Thus, such global happenings to a large extent predisposed and influenced the role local churches played in the transformation process in South Africa. Moreover, Swanepoel (2000:21) is of the view that South Africa as a country experienced and continues to experience a number of problems and challenges, such as high levels of poverty, unemployment, murder, other crimes, human trafficking and drug abuse amongst the youth, as well as child and women abuse. These challenges outweigh the HIV and/or AIDS pandemic. High levels of corruption, unemployment amongst the youth and increasing levels of child abuse appear daily in newspaper headlines. These problems are like a cancer, eating our moral fibre to the core. Furthermore, South Africa tends to be placed high only on negative index lists, whilst its scores on positive indexes are low and deteriorating. The country ranked 123rd (medium low) on the Human Development Report of the United Nations in 2011 (United Nations Development Programme [UNDP] 2011) and 128th (low and declining) on the environmental development index of 2012 (Yale/Columbia Index 2012). Furthermore, South Africa ranks amongst the top 10 countries in the world regarding murder and the total number of crimes committed [United Nations Office on Drugs and Crime (UNODC) 2012]. The number of recorded road deaths proportional to the country's population is close to the highest in the world (Scherer 2013). South Africa has the highest number of people living with HIV in the world (KFF 2012:1). These are immense stumbling blocks for our society and it seems that we are at a crossroad. The writer contends that the role of religion, and especially the roles of religious leaders - prophets, priests or pastors - is centrally concerned with addressing these challenges, whether through liturgies and other ritual practices, pastoral care, proclamation and interpretation, or helping to 
build communities in which people can find comfort, support and empowerment in the face of chaos.

Emanating from the introductory scenario, this article explores the role of the church as a reformation agency in enhancing a socially transformative agenda in South Africa.

\section{Literature review}

\section{The early church movements: From Radical Reformation to Second Reformation}

Before we start to discuss the emergence of the Reformation of the Church, we need to focus on the nature of Church. The concept, according to Okholm (2009:3), emerged not from the Scottish (kirk) and German (kirech), but originally from the Greek as kurios. The church reflects the body of the Lordship of Christ and serves as a witness to his Word. The mission of the Reformed tradition of the Church is traced in the biblical narratives in the Word. Let us look at events and awakenings such as wars, periods of unrest and instances of corruption in the history of the Church which spearheaded the early reformation process. Several scholarly reformists, such as Jan Hus, Peter Waldo, John Wycliffe, Martin Luther, Johan Calvin, John Knox and John Wesley, spearheaded the reformation process. One of the greatest Radical (Protestant) Reformationists, Martin Luther, who published his renowned work Ninety-Five Theses on the Power and Efficacy of Indulgences in 1517, started the acceleration agenda. These reformists were the voice-of-the-voiceless and protested against bribery, corruption and dishonesty in the early Church. These reformists - Luther in particular - used the Bible (Holy Scriptures) as their most commanding and authoritative tool in engaging the devoted followers of the church to break from the Roman Catholic Church. This ultimate breakaway from the Roman Catholic Church was further accelerated through Luther's sending of his well-known Ninety-Five Theses on the Power and Efficacy of Indulgences to the Archbishop of Mainz, prompted by his position on indulgences, corruption and doctrinal policies and the powerful authoritative position of the pope. What emerged from the Radical Reformation movement were three distinctive religious branches, namely, Anabaptism, Spiritualism and Socinianism or Evangelical Rationalism. A close look into the impact Radical Reformation notions had on the 'Reformed ecclesiology' of the 17th century and beyond - as well as the progress that these brought - shows several major changes to have taken place leading up to the Second Reformation.

The influential Radical (Protestant) Reformation movement set a clear path for the reformation agenda for the global reformed churches in the 21st century and beyond. It is therefore evident that spiritual leaders are compelled to exercise their historic role and constitutional duty to work together with government to achieve moral generation as a common cause to transform society. In view of this statement, an urgent degenderised morality for our society is needed, a 'transformed and reformed mind, soul and heart' as a prerequisite for an accelerated transformational agenda of society at large. In the context of this article, we need to understand the influence of Reformation on the contemporary church. From these origins a particular phenomenon called the 'Reformed ecclesiology' emerged. Scholars view ecclesiology (church or congregation) as the theological study of the origins, relationship and salvation plan of the Christian Church. Several types of ecclesiologies (denominations) have emerged from the early Reformation days, such as the Roman Catholic ecclesiology, the Lutheran ecclesiology and the Ecumenical ecclesiology (Holdcroft 2006; Okholm 2009; Pettegree \& Hall 2004).

In a nutshell, the literature indicates that the 'Reformation' as a 16th century religious movement had a great impact on both the church and on Christianity. This phenomenon has influenced and transformed the Roman Catholic Church and several 'reformed churches' emerged from this process. Moreover, Okholm (2009) is of the view that the early reformists protested against the Roman Catholic Church for a number of reasons. These included the use of the printing press, the increase in production of Protestant literature, a greater political autonomy and drastic increases in student enrolments in heterodox universities that adopted Protestantism in their curricula.

On the contrary, let us direct our attention to the next phase of the Reformation Church movement. The nature and influence of the Second Reformation on the Church after the 17th century will be briefly discussed. In view of the nature, characteristics and principles foregrounding this phenomenon, Smit (2013) is of the view that it is extremely problematic to reason about its nature because of its essential massive multiplicity. The author is of the opinion that there are several problematic issues at play, such as reformed identity, diversity, confession of faith and doctrine. These problematic issues indicate that the underlying diversity and nature of the Reformed theology is what Smit (2013:313-314) coined as 'a reformed identity challenge of church'. Despite these dilemmas, scholars of the Second Reformation movement based their arguments on specific principles that separate this movement from other religious movements as a universal church movement because of the Lordship of Jesus Christ. Furthermore, the church of Christ is founded on spiritual independence with the Word of God being the supreme and ultimate authority for the church. Moreover, all nations are subject to God and to the Lordship of Jesus Christ. Finally, the church is in covenant with God (DeVries 2016; Smit 2013; 2008).

Currently, scholars such as Gibbs (2001) and, in particular, Smit (2008), view the Reformed church globally as an extremely provocative phenomenon that can be a formative and transformative power to challenge social injustice in South Africa. Nonetheless, Gibbs (2001) and, in particular, Smit (2008), argue that there are specific features of the Reformed ecclesiology that are continually being updated and that motivate the African church community as those in other countries around the globe are motivated. 
Moreover, Okholm (2009:1) argues that the Reformed ecclesiology is the community of believers of Christ. To put this in simple terms, the church is about the members being a witness as believers of his Word. In addition, Smit (2008) summarises the Reformed ecclesiology vision:

It is also possible to argue that experiences of recent years and contemporary realities in Africa are again informing, inspiring and challenging Reformed churches and believers to see and act in very characteristic Reformed ways - or else to risk being unfaithful to the Reformed vision itself. For Reformed churches in Africa, this may indeed be a Kairos moment in which to reaffirm fundamental convictions of the Reformed faith and to be the church in the world in ways very much at the heart of this vision and spirituality. (p. 330)

In view of the latter by Smit (2008), and drawing from the dominant tenets of the Reformed motifs to advance the message of the Scripture, one concern is that the Reformed member churches on the African continent face the same challenges as part of the one body globally. Furthermore, Smit (2008) characterises the Reformed ecclesiology phenomenon as a:

formative and transformative power, it calls for embodiment in visible and concrete social forms. Since this Reformed spirituality is not other-worldly, this embodiment of the gospel must take place both in church and in society, and since the gospel must be heard ever anew, this embodiment is never completed, but continuous through history. (p. 333)

He continues by arguing, for the sake of church, for unity to become increasingly visible in Africa, in faith, in life and in service; for reconciliation to be practised, overcoming the deep divisions amongst them.

\section{The role and influence of the local church in the 21st century}

Scholars define 'religiosity' as a multifaceted social dynamic phenomenon because it cannot be easily defined or conceptualised. This phenomenon demands a rigorous scholarly endeavour which, in turn, requires a multidimensional reflection. It has attracted a great deal of interest across several academic disciplines, each approaching religiosity from a different perspective (Bergan \& McConatha 2000; Cardwell 1980:12). Moreover, scholars and theologians argue religiosity from the point of view of faith (Groome \& Corso 1999:65). Furthermore, Holdcroft (2006:89) indicates a couple canons of reflective religiosity, namely, religiousness, orthodoxy, faith, belief, piousness, devotion and holiness. Let us take a closer look, from a Christian point of view, at what religion is. Literature refers to this construct as a devoted act of service and worship to God or the supernatural. People take on a specific religion and they belong to a local denomination or church. The local church member becomes devoted in his or her relationship to a specific religion. For example, if a person decides to follow Jesus Christ, he or she becomes a follower of Jesus Christ (discipleship) by devoting him or herself to a relationship with Christianity as a religion. It is important to define briefly the role of religion in modern day society.
Currently, religion plays a very important role in a globalised dynamic society. According to Haar and Ellis (2006:99), religion is the only key feature of humanity in a political-ideological world and, currently, serious debates are emerging around this phenomenon. Moreover, Krüger, Lubbe and Steyn (2009:38) concur with the latter view that religion is the only political-ideological phenomenon which has stood against all onslaughts and demonstrated resilience in contemporary time. According to these African scholars, religion is a devoted truth of reality and reality is religion. Similarly, Magesa (2002) attests that, for Africans, 'the creation is apparently perceived as an organic whole a devoted reality of truth' (p. 129). In this case, for the South African local church, ministers need to understand their specific role in order to achieve the transformative agenda.

In order to contextualise the church in a democratic South African dispensation, I utilise Geertz's (1973:89) notion of religion as a cultural system to examine how micro-level social relations, as reflected in the healing rituals of St. John's, impact and are impacted by macro-level political, social and economic structures and struggles in South Africa. Furthermore, Geertz posits that religion plays a significant role in the social life of people by functioning as a symbolic form which integrates the way that they construct their lives. Thus, the interpersonal social relations of poor black South Africans are examined with the intent of discovering how they employ healing rituals as a force for reorienting their social reality - a material world that is permeated with the legacy of Apartheid - and symbolically transforming it into a life-enhancing reality. The transformations are necessary, even during the present new democratic dispensation, because the insidious effects of both ideologies and practice still perpetuate structures that diminish human life. According to Rick Warren, the world is urgently in need of a Reformation and South Africa is in particular need - a Reformation not of creeds but of deeds. In the same vein, Warren (1995) delivered an emotional speech whereby he argued the case for an urgent need for a Reformation. He pleads for an agency amongst churches to show action through deeds to accelerate the transformation process. My limited take on Pastor Warren's statement 'No creeds but deeds' is that I prefer to say 'our creeds must lead to deeds'. I do not think that it is a case of 'either creed or deeds' but rather that both creeds and deeds are needed to reflect God's Kingdom life effectively amongst the lost. Deeds without righteous faith are again dangerous as they may produce self-righteousness. This reminds me of the important truth revealed by the Apostle James in the Book of James where he says, 'Faith without works is dead'. It is therefore time for the church to speak out against all evils such as increased corruption amongst political and business leaders, racism, rape, bullying and human trafficking in South Africa. In addition, Oladipo (2001:220) maintains that the church can play a pivotal role as moral regenerator, builder, a valuesbased organisation for the poorest of the poor, advancing cultural diversity and building relationships amongst communities and across racial barriers to transform the 
current society. To adopt this paradigmatic approach, the church must review its current role but must not forsake the mandate to preach the good news, make disciples and teach and act in relevance in a secular world.

Gibbs (2001), the author of a book entitled Christianity Today, posits that the church should play a critical role in the transformation process if it is to be relevant in the 21st century and beyond. In the book, the author highlights specific challenges faced by Christianity to be relevant. Moreover, Gibbs (2001:23) argues that the current church must change 'to be biblically true to its message and its mission to the world'. Before we focus on what the church is and the role it can play in the new democratic dispensation, we must take a closer look at the particular roles played by clergy and spiritual leaders. According to Geertz (1973:87) church leaders must understand their calling as ministers of the pulpit, they must understand the concept theotokoi which means the 'God bearers', or 'representing God to the people and the people to God'. It is their role to create spaces through their sermons to bring church members into a relationship with their Creator. However, McFadyen (2016) articulates that:

It is also why Christian faith turned to the image of God as its main conceptual placeholder to understand human being as related to by God; not because it looked first to the creation narratives in search of an original essence and found the phrase there, but through a strong sense that Jesus was actively imaging God in his life, death and resurrection. (p. 127)

In addition, another angle on this debate suggests why the local church must turn to the image of God through preaching, worship leadership, teaching and pastoral counselling - central interpretative and community building roles. These are enduring aspects of what clergy do, whether at the present time, in the past or into the foreseeable future. There are, therefore, indispensable and enduring dimensions of the role that religion and religious leaders play in daily life that have changed little over time and about which there is considerable consensus in advancing the Christian faith. In summary, the church leader must provide specific opportunities and possibilities for the church to be a relevant practical church. I believe that this helps to explain why so many clergy in our study said that being a pastor is a deeply fulfilling and satisfying vocation. Not only did a large majority from all faiths express a high degree of satisfaction with their ministries, but also very few said that they had ever seriously doubted their calling. These responses surprised many, myself included, especially having listened to clergy 'bitch and moan' sessions and heard numerous reports of low morale amongst the clergy. To be sure, being a pastor is not easy; clergy face numerous problems as they go about their work. Yet, for the most part, these problems do not outweigh the intrinsic rewards that come from the enduring aspects of the clergy role: pointing to God's presence in the face of all that threatens to make life meaningless, helping people connect with each other in supportive communities and helping them to reach out to others in their need.

\section{The local church in search of excellence}

The church is an organisation to strive for excellence in service towards members and it must be managed according to specific business principles and practices relevant in contemporary era. Building on this idea, Peters and Waterman (1982) published a book entitled In Search of Excellence. With reference to the book, the authors provide specific characteristics of what a notion of 'only excellent organizations will survive' entails in this globalised crisis. Throughout their book, the authors discuss cases concerning how to manage an organisation or a business according to specific qualities that businesses and corporations exhibit. These principles and qualities can be used by the local church as a blueprint towards church growth, change and transformation. A selection of important qualities in searching for excellence is listed below:

- The voice of the customer counts: listening to and satisfying their needs.

- Setting a vision: strive to a vision of what one wants to accomplish.

- Paying attention to the smallest details.

- Instilling in all employees the values of the company.

- Providing staff and leaders with the training needed to do their jobs well.

- Listening to participants and valuing their input (Gibbs 2001:26-29; Peters \& Waterman 1982).

According to Thompson (1984:555, 709), the contemporary church leader can use biblical principles as measures to manage and instil practices of excellence in servicing their respective church communities. Having established the importance of searching for excellence in the church, scholars highlight specific areas for the local church to be of relevance, namely:

- from being market-driven to being mission oriented,

- from following celebrities to encountering saints,

- from holding dead orthodoxy to nurturing living faith, and

- from attracting a crowd to seeking the lost (Beckham 2006; Gibbs 2001:26-29).

To accomplish these within the search for excellence, churches must therefore generate a convincing atmosphere for members and visitors. For the local church, the virtue of excellence is everything - there can be no compromise in small things. From the moment the visitor or 'newcomer' arrives at the doorstep of the church up until the closing of the service, do they experience excellence? Do they feel at home or loved? Excellence cannot be compromised because first impressions last - from accepting visitors or newcomers (guests) at a church service by doing a follow-up, by either calling or paying visits. As part of a formative as well as transformative agenda, it is up to churches to inspire their congregations to search for excellence. Churches can use strategies such as empowering members and creating opportunities to grow spiritually, developing knowledge through sound biblical principles, setting standards that will 
influence every sphere of life and equipping them for service.

\section{The relevance of the Reformed church as the prophetic voice and witness}

Local churches cannot escape the impact of globalisation and it is therefore reported that nearly $80 \%$ of the South African population is said to be Christian (Statistics South Africa [StatsSA] 2014). Moreover, Christians are in the majority which means that Christian churches must be the voice of marginalised and the poor and must become so by challenging immorality in the country. If the church during the Apartheid era could stand up for social injustice, why now in this hour of crisis does it turn a blind eye to evils such as rape, crime, drug abuse, corruption and other immoral evils in society? The church should and must be the prophetic voice and witness to demonstrate God's love for humanity. Scripture proclaims, according to Psalm 8, verse 4: what is mankind that you are mindful of them, human beings that you care for them? Therefore, the local church must demonstrate God's unconditional love for mankind because, according to Genesis 5, verse 2, we are all created in his image. According to McFadyen (2016:127) and Olodipo (2000), Christian churches must 'share a common purpose and function, seeking of full humanisation in relation to God, self and others'. To demonstrate this unconditional love, Christian ethics are embedded in brotherly love, forgiveness and honesty. The local church is the prophetic voice and witness of the Church of Jesus Christ as a means to accelerate the Reformation process in South Africa. With reference to this article, an example in the 'Epistle to the Namibians', quoted in Katjavivi (1989:136-138), indicates how the Namibian churches have been hailed for their strong stance against the Apartheid regime. The writer, therefore, concurs with the latter statement that South African churches cannot be silent on crimes against humanity and must, therefore, be the voice of the masses in the same way that it was during the Apartheid system. The local churches must be the sounding board, becoming the carrier of the message of hope, justice and freedom for all South Africans.

In recent times, realities on the African continent have shown how churches use unity as an advantage by updating, motivating and advancing thought-provoking issues for the contemporary church to act upon or react to against political, economic and social injustices. There are many examples how the church united globally - but how one particular movement on the African continent spearheaded the Reformed church movement. According to Meiring (1991), the Belhar Confession (1986) emerged as a powerful church unity movement during the Apartheid era. This movement later changed its identity to the Uniting Reformed Church in Southern Africa (URCSA) in order to include all other sister churches in South Africa. The questions remains: What made the URCSA such a powerful driving force towards social justice during the Apartheid era? This church movement was the 'voices for the voiceless' and still today challenges the social injustices in society locally as well as globally under the umbrella of the World Council of Churches. In view of this movement and the Reformed vision expressed by Smit (2008), African Reformed ecclesiological scholars see these changes as 'kairos moments' to reiterate critical pursuance of the Reformed faith and to be at the heart of this vision and spirituality (Katjavivi 1989; Koopman 1986; Maluleke 1998; Smit 2003). Furthermore, the ultimate message of the Scriptures, but in particular the gospel of Jesus Christ, is to be preached, heard anew, again and again, in ever-changing socio-historical circumstances. It is therefore crucial for the Christian churches be the prophetic voice and witness of a relevant church community in Africa, but in particular in a democratic state such as South Africa, to accelerate the Second Reformation process. There is a saying that unity is strength - evidently, if local churches stand together in unity, such unity will overcome injustices in our society. If these churches focus on the sentiments echoed by Smit and leave the painful past, strife and critique, and if they resist all forms of injustice, to serve justice and fullness of life for those many who suffer every day, then the transformation of the Second Reformation could possibly be witnessed in our lifetimes.

\section{Methodology}

This article employs a qualitative research design. The strength of the qualitative paradigm is that people are studied in terms of their own definitions of the world - in other words, from the insider perspective. The qualitative paradigm focuses on the subjective experiences of individuals and it is sensitive to the contexts in which people interact with one another (Rogers 2012; Van Wyk \& Taole 2015). A qualitative research approach was used to elicit an interpretative phenomenology (IP) design to negotiate a shared understanding through conversation and intersubjective meaning-making with church ministers, with the primary focus being their subjective experience of the changing role of the church in enhancing a formative and transformative agenda in a South African context. IP is increasingly recognised as a useful tool in humanities, in particular in religious research studies. It is the view of the researcher that IP has the strengths to recognise contextual factors which may influence how individuals construct meaning from their own experiences and, as such, was thought to be an appropriate method for use within this study. Purposive sampling participants are selected according to what they already know about the field (church leaders) and because they have certain characteristics in common that relate to the topic of the study (Merriam 2009). The reason for choosing purposive sampling is that qualitative research is more concerned with detailed and in-depth analysis than with statistical accuracy (Terre Blanche \& Durrheim 1999:45; Van Wyk \& Taole 2015). The purposive sampling $(n=6)$ consisted of two senior male pastors (Apostolic Faith Mission of South Africa), a male Bishop (Living Waters Ministry SA), a female reverend (Methodist Church), a male pastor (Assemblies of God South Africa Church) and a male pastor (Christian Revival Church South Africa) who participated in the study. Specific times for interviews were scheduled with identified church leaders. Face-to-face and telephonic semi-structured 
interviews were conducted and these were scheduled for 20 minutes per session. For conducting the research, the main research question is: What role does the local church as a reformation agency play in enhancing a socially transformative agenda in South Africa? To answer the main research question, the following secondary questions were formulated: What is your view of transformation and how can your local church use this principle or strategy to bring change to better the lives of your congregation? Elaborate and give any examples of project(s) your church has implemented over the past 5 years regarding transformation. What is your understanding of the concept of 'reformation' and do you believe that you are a reformist in your local church community? To what extent do you believe that the local church is in line with God's redemption plan for the secular world? Please elaborate. What are the challenges your church faces and what specific role can the church play in enhancing a socially transformative agenda in South Africa?

Before the study could commence, the researcher explained the purpose of the study to participants. No names or other identifying details of respondents may be revealed, except for research purposes. The interviews were recorded, transcribed, read, evaluated and analysed, and each sentence was carefully coded. A constant comparison data analysis method was used and different themes were identified. In this case, the researcher had to piece together different transcripts as pieces of interviewees responses, creating a collage of information from the data collected. After the completion of the data analysis process, the original recorded versions of the interviews and transcripts were made available to a senior research professor in the department who specialises in qualitative research designs, with a request to validate the trustworthiness and authenticity of the content in relation to respondents' responses to the questions that emerged from the analysed data. After a week of data verification and validation, she reported that she was satisfied that the correct protocol had been followed and thereby validated the process of data collection for this article. All data displayed in this article are inductive and deductive in nature.

\section{Findings and discussion}

The biographical data of the purposive sampling consisted of four male $(66 \%)$ and two female $(34 \%)$ church leaders who participated in the face-to-face and telephonic interview sessions. Participants were well qualified and comprised two church leaders (BA Theology and Professional Teachers Diploma), one male church leader (MA Theology) and three church leaders (Diploma in Theology). All had several years of experience in the ministry, ranging from 10 to 36 years.

The following sub-research questions were formulated for the data collection process. Different themes were identified during the data analysis process:

What is your view of transformation and how can your local church use this strategy to bring change to better the lives of your congregation? Give any examples of initiatives or project(s) your church has implemented over the past five years.

\section{A lived transformational experience of the church towards changing the lives of a church community}

To accomplish this, church ministers are compelled to create 'lived experienced' opportunities for members as an inward-outward spiritual journey. The congregation must experience how the local church support and help changing their lives. According to Casanova (2001:434), Contemporary Pentecostalism may serve to prove or provide the likely favourable changes which globalisation offers to a highly decentralised religion. Moreover, from Catholicism to Charismatism, it seems that these church movements have a vastly centralised transnational network of human, institutional and material resources, and therefore feel confident in their ability to thrive in a relatively open global system of religious regimes. Pastor Cornelius (Missions Strategy Coordinator in Chiang Mai, Thailand) alluded in his response to transformation as experienced by people in the church and in society. He goes further by stating:

'Transformation is a change reaction reflected in the lives of people who have been impressed upon to be transformed. It is a process and it takes one who is ready to transform others and people who are ready to be transformed. I see transformation as a big part of development and when it happens it is qualitative because it is seen in the lives of the transformed.'

In a post-millennium church movement, opportunities to further drive the process of transformation in a globalisation context offer transnational religious regimes opportunities to advance the Reformation. In addition, Bishop Johannes (Living Waters Ministry) responded, in a sense, to transformation as a way of life by relating his experience which had changed from inward to outward living spiritually. He quoted Scripture to substantiate his point of view as to why he, as a church leader, believed people need to experience transformation as a lived experienced:

Transformation means 'change or renewal from a life that no longer conforms to the ways of the world to one that pleases God' (Romans 12:2). This is accomplished by the renewing of our minds, an inward spiritual transformation that will manifest itself in outward actions. The Bible presents the transformed life in Christ as demonstrated through our 'bearing fruit in every good work [and] growing in the knowledge of God' (Colossians 1:10).

Further utterances by the church leaders (Cornelius, Samuel and Josef) revealed why they believed the church to be receiving a clear mandate to drive the transformation agenda towards the Reformation.

They agreed:

Transformation involves a changing of life in Christ. In its temporal dimension, the legitimacy of the modern age entails the acceptance of the principle of historicity, the continuous revelation of God's plans of salvation in and through history, and thus the church's obligation to discern prophetically 'the signs of the times'. 
Furthermore, Pastor Cornelius (Missions Strategy Coordinator in Chiang Mai-Thailand) alluded in his response to specific examples of projects. He indicated telephonically that he and local church leaders were running the street children and child trafficking initiatives and working closely with the Thai authorities (Police, Education and the religious community). He said that he had 'lived experienced opportunities' of more than 10 years with the Thai-people who became believers in the Missions Strategy, both in respect of the local church and in society.

\section{He went further, stating:}

\begin{abstract}
'Yah, a good example is the CRC Missions Strategy Abroad, which started in 2010. We planned with outreaches in rural towns of Chiang Mai, in northern Thailand. The people are very poor in this region. I mean the poorest of the poor. You cannot preach the Gospel and expect these people listening with a hungry stomach to the message. It will not work. You need to feed the hungry. We started with several feeding schemes to reach the poor. We also started a literacy project because many of the rural Thai-people is illiterate. We first trained the local leaders and used them as interpreters.'
\end{abstract}

In summary, church leaders viewed transformation as a very important process towards changing society. They felt that the local church could use this strategy to bring change to better the lives of the congregation and community. They agreed that, before the Reformation could emerge in our lifetime, church ministers informed us that a prerequisite must exist to drive the transformation process. They believed that transformation is in line with God's redemption plan; it is a 'lived experience' in the renewal of the heart, soul and mind, it is an inward-outward spiritual journey of the church. The church must respond to needs to take up the challenges in society to drive the reformation agenda. Excellent examples of initiatives or project(s) were given by church leaders which were implemented over the past 5 years:

What is your understanding of concept reformation and do you belief you are a reformist? To what extend do you believed that the local church is in line with God's redemption plan for the secular world? Please elaborate. What specific role can the church play in enhancing a socially transformative agenda in South Africa?

From the data analysis process, certain themes emerged, such as a conceptualised view of reformation, servant leadership as a virtue in formatting and transforming society, the voice for the voiceless and creating Kingdom Life spaces which were established in the search for excellence and to drive the transformation agenda. Each of the themes will be discussed.

\section{A conceptualised view of a reformation agent}

The majority of the respondents agreed that they were reformation agents because they do you belief they are reformists and visionaries. Respondents indicated that the community which they serve daily as church leaders start from daily visitations to social issues as a calling into ministry. They must help from spiritual to socio-emotional issues.
They said that they are involved in many community structures because the community sees them as part the transformation agenda not only as spiritual leaders but to serve the community where need arise. Pastor James (African Faith Mission [AFM]) was very excited to answer the interview question:

'To your question, yes, I am a reformist like my late father. $\mathrm{He}$ was the founder pastor who started the Apostolic Faith Mission Vryburg church twenty two years ago. Jah, I was born and baptised into the family of the AFM Pentecostal Reformed Church. I am definitely a reformist because I am for change for the betterment of our community. I am currently serving the AFM Heidedal congregation.'

According to Omar (1999:27), the local church is influenced and driven by the reformation agenda in a secularised state. Moreover, Omar continues that contemporary churches, in particular the 'religious leaders are obliged to maintain their historic role of being the moral conscience of society and raise their voices of protests against ... violations of human dignity' (p. 27). It is therefore evident that church leaders are compelled to exercise their historic role and constitutional duty to work together with government to achieve moral generation as a common cause to transform society.

\section{Servant leadership: A virtue in formatting and transforming society}

Literature indicates that servant leadership is equally a leadership philosophy and set of leadership practices in which the servant-leader shares power by putting the needs of others first and helps people develop and perform as highly as possible in their respective duties (Hall 2007; Hexham \& Poewe 1994). Moreover, Gibbs (2001:23) argues that the current church must change 'to be biblically true to its message and its mission to the world'. The respondents came up strong on servant leadership as virtue in formatting and transforming society. They see it as a calling from God into ministry. Both Pastor Alice (Assembly of God Ministry) and Josef (Pentecostal minister) quoted Scripture to substantiate their stance as to why church leaders need to demonstrate to servant leadership. Both agreed that they had been called to service:

The church remains very important in transforming people's lives today more than ever because successive governments have failed the people, families are too busy chasing the things of the world rather shaping the lives of the future generations, civil societies are fighting for rights that are not endorsed by the Holy Bible.

Respondents indicated that servant leadership is a way of life, philosophy in practice to lead and to serve in a collective process. The objective is to serve others' needs and to help them to perform to best of their abilities in their respective duties.

\section{Voice for the voiceless - 'Our creeds must lead to deeds'}

The church must declare creeds that lead to demonstrable deeds, meaning that injustices faced by the voiceless in society 
must be voiced or disapproved of. No church leader should be silent and all must speak out against unjust practices in society. The Church in the 21st century has to integrate the three mandates into one mission or ministry as we pursue the goal of seeing his Kingdom come globally. The mandates are the creation mandate (increase and multiply), the great commandment (love God, neighbour and self) and the great commission (go and make disciples). Josef (Pentecostal minister) quoted Scripture to substantiate his point of view as to why he as a church leader believed that churches needed to demonstrate both creeds and deeds - meaning the church in-action to voice injustices. He substantiated his point by quoted, James 2, verses 14-19:

What good is it, my brothers and sisters, if someone claims to have faith but has no deeds? Let's give you an example, last week when we as the church celebrated Fathers' day, I preach on this from Scripture. During my sermon you could felt how unease the church was, notwithstanding me. We need sometimes to preach thought provoking issues, especially now that we in our country experienced issues of racism, crime and drug abuse. The church must declare creeds to reconcile people with God but the church function is to lead by demonstrating deeds. Yah ... action speaks louder than words.

In view of Josef's statement, the church has a clear mandate to show love for one another as a commandment through action. Furthermore, Essien (2015:86) and Maluleke (2001) argue that the faith of every believer in all communities is instituted by law as a basic component of human dignity in particular the church in an African context. To expand on this view, with reference to the Constitution of the Republic of South Africa (Republic of South Africa, 108 of 1996 as Amended), Bill of Rights: Section 18: Freedom of association protects religious freedom as a fundamental right of humanity. Emanating from the secular law, Pastor Alice (Assemblies of God ministry) wholeheartedly agreed on the issue of human rights. She is of the view that ministers must practice what they preach from the Scripture. She echoed the following sentiments:

'Yah, you know, Christians are different from other religions because the book of James gives the church a clear message. This part of Scripture for me talks a lot about faith and 'faith without works is dead'. Hence, we need leaders who will practise what they preach so people will trust them and follow them. There are so many church leaders who are doing fantastic work in their respective communities.'

She continued by quoting Scripture from James 2, verses $15-18$, to underscore her view that deeds in action are powerful tool in advancing Kingdom life:

Suppose a brother or a sister is without clothes and daily food. If one of you says to them, 'Go in peace; keep warm and well fed', but does nothing about their physical needs, what good is it? 17 In the same way, faith by itself, if it is not accompanied by action, is dead. 18 But someone will say, 'You have faith; I have deeds'. Show me your faith without deeds, and I will show you my faith by my deeds.

During the face-to-face interview session, Pastor Alice (Assembly of God Ministry) highlighted the importance of youth development as part of the church community. According to her, she was very worried about the youth and it seemed to her that churches had lost their grip on the youth. She referred to the following:

'Yah ... we as the church must do more to include the youth of our planning because they are the leaders of tomorrow. The 21st century tools that Satan is using to destroy the lives of the youth can be used to proclaim the Gospel and make people useful in their lives than what we are seeing today. The youth of today uses social media, for example Facebook, WhatsApp and other networking tools for bullying, crimes etcetera. We need to do more for our youth so they feel we care for them.'

The sentiments echoed by the interviewed church leaders are likely to force local churches to be more sensitive to the needs of the modern youth, to be realistic and to rethink strategies to include them in their future plans. Churches will be compelled to accommodate the youth as a priority because they are the leaders of tomorrow.

Based on the views expressed by the respondents, church leaders agree that, despite the considerable social, cultural and religious change in the past decade, ministers of the pulpit show widespread consensus about their role, a consensus that seems, at least on the surface, to have changed very little over time. They believe that creeds are for new babies (new born in faith of Jesus Christ) and they also informed us of their view as to why other religions are currently so violent - this is because they believe so strongly in creeds. In summary, they all agree that the church must 'live' 1 Corinthians 13 as a great commandment to the church to express Kingdom life through love in action. Churches must become that voice of the voiceless by disapproving of societal injustices.

\section{Challenges to serve and to be relevant as a multicultural and diverse church in the 21st century}

Over the past two decades, the 21st century Church has experienced several challenges relevant to serving its mandate in a multicultural and diverse community. Under this theme, church leaders expressed serious concerns as to the capacity of the local Church to be a reformation agency able to serve and to be relevant as a multicultural and diverse church up to the challenges of the 21st century (Carroll 2002). It was very interesting that church leaders with several years in ministry mentioned their respective issues and challenges faced over time. They indicated a lack of practising and promoting stronger unity and reconciliation in the Church. Josef (Pentecostal minister) echoed the following regarding church unity and reconciliation:

'We as the Church need to work together as the body of Christ and not each other to steal others sheep. In our community there are a couple denominations such Pentecostal to Grace Church. If the secular world sees that we local churches cannot work as a united church front, the devil will ultimately create chaos amongst us. We [I mean black and white churches must in this town] need to stand together and practice where possible reconciliation.' 
Smit (2008:334) conducted a similar study and reported several similar challenges with regard to overcoming the deep divisions amongst churches though this study did not voice any views in relation to social injustices in South Africa. On the issues of promoting reconciliation amongst sister churches, van der Merwe (2003:269-281) reported that churches in South African are in a unique position to take the lead and to address this challenge head on because it in line with Christianity and Scripturally founded truths. The church leaders felt that most churches could not deal with issues of moral renewal and the slow pace of social transformation in the Church. According to Duncan (2002:341), this issue remains a huge challenge for the local Church because it cannot work alone in changing the problem of moral regeneration and social cohesion. This must be a collective effort on the part of all stakeholders. Moreover, Oladipo (2001:220) and Morgan (2016:326) concur with the latter view that the church community can play a pivotal role as a builder of moral regeneration, advancing cultural diversity and building relationships amongst communities' across racial barriers to transform our current society. The majority of the church leaders indicated a lack of sound relationships and expressed concerns about the deep divisions in the Church community. Furthermore, they felt that churches must resist all forms of injustice, corruption and discrimination in the Church and community. On this point, Pastor Alice (Assembly of God Ministry) highlighted how, in some churches, women experienced the challenge in being servants of the Church. She said: We need to include issues that remain a glass ceiling for empowering women in the Church. In addition, Phiri (2005) conducted a study on the major challenges faced by African women. The author found that the Church needs to address the crucial issue of women in ministry and therefore need to align and engendering the theological curricula from discrimination and male dominance and create a more inclusive theological education. Respondents also indicated there was no clear path and role for the Church to play in the 21st century. These are serious multiplicity issues that need to be addressed by the Church as community working towards changing society. The participants felt that the local church must overcome these challenges and convert them into opportunities or strategies to bring change in order to better the lives of the congregation and community at large.

\section{Conclusion}

The current dispensation and recent global happenings have, to a large extent, predisposed and influenced the role local that churches are able to play in the transformation process in South Africa. This article has reported that the church as a change reformation agency could be the driver for a formative and transformation agenda in enhancing the Reformation by eliciting in addressing the socio-economic needs in the new democratic dispensation. Clearly, this study has shown that the main issues which impact the enhancing of the Reformation are creeds, and that these must lead to deeds, that churches must be a voice for the voiceless, that they must create spaces for searching for excellence and increasing servant leadership in order to format and transform society. To accomplish this goal, church ministers are required to spearhead this challenge as a prerequisite. Church leaders believed that transformation as a process has a secular dimension, but that it can be aligned towards God's redemption plan. In line with the church as a change agency, people must experience a 'lived experienced' as an inwardoutward spiritual journey. To accelerate the Reformation process, dimensions such as faith, servant leadership and the search for excellence could enhance this phenomenon. Church leaders agreed that, despite the considerable social, cultural and religious challenges of recent times and showed widespread consensus about their role having changed very little over time. Furthermore, they indicated that servant leadership is a social phenomenon, a philosophy-in-practice to lead by example and to serve as a collective in order to achieve a specific goal. They believed that Scripture mandates Christians 'from the beginning to the end' has always emphasised the importance of God's Kingdom in reality and/or life and that the church is the only vehicle for eternal truth and reality. The church must be ready to accommodate change 'to be biblically true to its message and its mission to the world' so that the Second Reformation can be accomplished and become a reality. To accomplish this, church ministers are required to spearhead the challenge as a prerequisite by creating 'lived experienced' for members as an inward-outward spiritual journey. Finally, church leaders believed that transformation has a secular dimension but that it can also be aligned towards God's redemption plan and can enhance a socially just transformation agenda. The results of this study cannot be generalised because of the selected sample size ( $n=6$ participants), time period conducting the investigation ( 3 months) and nature of the research design (qualitative approach) which was chosen. A bigger sample and a different research design approach will definitely yield different findings. Ultimately, the findings of this study proposed several practical recommendations for the local church to be relevant in practicing and promoting stronger unity and reconciliation amongst all churches nationally and globally. Furthermore, the Church needs to plan and implement moral renewal and social transformation strategies as a priority. Moreover, fostering and establishing sound relationships in order to overcome deep divisions amongst sister churches in South Africa must be high on the transformation agenda. To be relevant, the Church must criticise and resist all forms of injustice, racism, corruption and discrimination as are currently experienced in the local Church. Finally, churches need to rethink global trends concerning the role of the local Church in the 21st century and beyond as a driver towards social transformation, harmony and peace.

\section{Acknowledgements}

The author acknowledges the church leaders who voluntarily participated in this research study. The quality of language revision work done by the university language editing unit is highly appreciated. Any opinions, findings and conclusions expressed in this article are those of the author and do not 
reflect the views of the Department of Curriculum and Instructional Studies in the College of Education.

\section{Competing interests}

The author declares that he has no financial or personal relationships which may have inappropriately influenced him in writing this article.

\section{References}

Beckham, W., 2006, The second reformation: Reshaping the church for the 21st century, Touch Publications, New York.

Bergan, A. \& McConatha, J.T., 2000, 'Religiosity and life satisfaction', Activities, Adaptation and Aging 24(3), 23-34. http://dx.doi.org/10.1300/J016v24n03_02

Cardwell, J.D., 1980, The social context of religiosity, University Press of America, Lanham, MD.

Carroll, J.W., 2002, “The more things change...": Pastoral leadership for the 21s century', in The Ernest Cadman Colwell lecture at the Claremont School of Theology, September 12, pp. 1-16.

Casanova, J., 2001, 'Religion, the new millennium, and globalization', Sociology of Religion 62(4), 415-441. http://dx.doi.org/10.2307/3712434

DeVries, B.A., 2016, 'Spiritual gifts for biblical church growth', In die Skriflig 50(1) a2090. http://dx.doi.org/10.4102/ids.v50i1.2090

Duncan, G.D., 2002, 'A place in the sun?: The role of the church in moral renewal and social transformation', Verbum Et Ecclesia Journal 23(2), 231-239. http://dx.doi. org/10.4102/ve.v23i2.1198

Essien, E.D., 2015, 'Ethical evaluation of African religiosity amidst violent conflict and crisis in Africa in contemporary time', International Journal of Humanities and Social Science 4(11), 86-100.

Geertz, C., 1973, The interpretation of cultures, Basic Books, New York, pp. 87-125.

Gibbs, E., 2001, The church today: Church next: Quantum changes in how we do ministry, InterVarsity Press, Chicago, IL.

Groome, T.H. \& Corso, M.J., 1999, Empowering catethetical leaders, National Catholic Educational Association, Washington, DC.

Haar, G.T. \& Ellis, S., 2006, 'The role of religion in development: Toward a new relationship between the European Union in Africa', European Journal of Development Research 18(3), 351-367. http://dx.doi.org/10.1080/09578810 600893403

Hall, T.M., 2007, Becoming authentic: The search for wholeness and calling as a servant leader, Cloverdale Books, New York.

Hexham, I. \& Poewe, K., 1994, 'Charismatic churches in South Africa: A critique of criticisms and problems of bias', in K. Poewe (ed.), Charismatic Christianity as a global culture, University of South Carolina Press, Columbia, SC.

Holdcroft, B.B., 2006, 'What is religiosity?', Catholic Education: A Journal of Inquiry and Practice 10(1), 88-103.

Katjavivi, P., 1989, 'Epistle to the Namibians', in F. Frostin \& D. Mbuende (eds.), Church and liberation in Namibia pp. 136-138, Pluto Press, London.

KFF, 2012, The global HIV/AIDS epidemic, viewed 29 January 2012, from http://kff.org/ hivaids/upload/3030-17.pdf

Koopman, N.N., 1986, 'Reconciliation and the Confession of Belhar 1986. Some challenges for the Uniting Reformed Church in Southern Africa', Nederduitse Gereformeerde Teologiese Tydskrif 48(2007), 96-106.

Krüger, J.S., Lubbe, G.J.A. \& Steyn, H.C., 2009, The human search for meaning: A multireligion introduction to the religions of humankind, Van Schaik Publishers, Pretoria.

Magesa, L., 2002, African religion: The moral traditions of abundant life, Orbis Books, Maryknoll, NY.

Maluleke, T.S., 1998, 'African traditional religions in Christian mission and Christian scholarship: Re-opening a debate that never started', Religion and Theology 5(2), 121-137. http://dx.doi.org/10.1163/157430198X00011

Maluleke, T.S., 2001, 'Identity and integrity in African theology: A critical analysis', Religion and Theology 8(1), 26-39. http://dx.doi.org/10.1163/157430101X00026

McFadyen, A., 2016, 'Redeeming the image', International Journal for the Study of the Christian Church 16(2), 108-125. http://dx.doi.org/10.1080/147422 5X.2016.1196539
McLeod, H., 2015, 'Christianity and nationalism in nineteenth century Europe' International Journal for the Study of the Christian Church 15(1), 7-22. http:// dx.doi.org/10.1080/1474225X.2015.1020009

Meiring, P., 1991, 'The Belhar Confession 1986: The Belhar Confession: A Dutch Reformed perspective', Theological Forum XIX(1).

Merriam, S.B., 2009, Qualitative research: A guide to design and implementation, Jossey-Bass Publishers, San Francisco, CA.

Morgan, J.R., 2016, 'Global trends and the North American church mission: Discovering the church's role in the twenty-first century', International Bulletin of Mission Research 40(4), 325-338. http://dx.doi.org/10.1177/2396939316664693

Okholm, D., 2009, 'Reformed ecclesiology: The community of Christ', Presbyterians for Faith, Family and Ministry 15(1), 6.

Olodipo, J., 2000, 'The role of the church in poverty alleviation in Africa. Transformation', Christian Faith and Economics Revisited 2(11), 146-152.

Oladipo, J., 2001, 'The role of the church in poverty alleviation in Africa', In B. Deryke, R. Caldesi \& C. Sugden (eds.), Faith in development: Partnership between the World Bank and the churches of Africa, pp. 219-236, World Bank and Regnum Books, Oxford.

Omar, R., 1999, 'Does public policy need religion?', in J. Cochrane (ed.), pp. 26-29.

Peters, T. \& Waterman, R., 1982, In search of excellence, Harper and Row, New York.

Peters, T. \& Waterman, R., 2006, In search of excellence: Lessons from America's bestrun companies, Harper Collins Publishers, New York.

Pettegree, A. \& Hall, M., 2004, 'The reformation and the book: A reconsideration', The HistoricalJournal47(4), 785-808. http://dx.doi.org/10.1017/\$0018246X04003991

Phiri, I.A., 2005, 'The circle of concern African women theologians: Its contribution to ecumenical formation', The Ecumenical Review 57(1), 34-41. http://dx.doi. org/10.1111/j.1758-6623.2005.tb00216.x

Republic of South Africa, 1996, Constitution of the Republic of South Africa, Act 108 of 1996 as Amended, Bill of Rights: Section 18: Freedom of association protects of religious freedom, Government Press, Pretoria.

Rogers, M., 2012, 'Contextualizing theories and practices of bricolage research', The Qualitative Report 17(7), 1-17, viewed 12 March 2015, from http://www.nova. edu/ssss/QR/QR17/rogers.pdf

Scherer, F., 2013, 'Policy options for reducing road accidents in South Africa', in Political analysis South Africa, viewed 28 July 2016, from http://www. politicalanalysis.co.za/2013/01/04/policy-options-for-reducing-road-accidentsin-south-africa/

Smit, D.J., 2003, 'No other motives would give us the right - Reflections on contextualised from a reformed perspective', in M.E. Brinkman \& D. van Keulen (eds.), Studies in reformed theology, pp. 130-159, Meinema, Zoetermeer.

Smit, D.J., 2008, 'Challenges for reformed churches in Africa: A contemporary narrative', International Journal for the Study of the Christian Church 8(4), 319-336. http://dx.doi.org/10.1080/14742250802347018

Smit, D.J., 2013, 'Trends and directions in reformed theology', The Expository Times 122(3), 313-526.

Statistics South Africa, 2014, Census 2014 by province, gender, religion and population group, Census 2014. Statistics South Africa, viewed 12 July 2016, from https:// en.wikipedia.org/wiki/Religion_in_South_Africa

Swanepoel, H., 2000, 'The dynamics of development', in F. de Beer \& H. Swanepoel (eds.), Introduction to development studies, pp. 71-84, Oxford University Press, Cape Town.

Terre Blanche, M.J. \& Durrheim, K., 1999, Research in practice: Applied methods for the social sciences, University of Cape Town Press, Cape Town.

Thompson, C.F., 1984, Thompson Chain-Reference Bible. New international version. The Old and the New Testament, Zondervan Bible Publishers, MI.

United Nations, 2011, United Nations Development Programme, Human Development Report 2011 sustainability and equity: A better future for all, Palgrave Macmillan, New York.

United Nations Office on Drugs and Crime (UNODC), 2012, World Drug Report 2012, viewed 29 July 2016, from https://www.unodc.org/unodc/en/data-and-analysis/ WDR-2012.html

Van der Merwe, H., 2003, 'The role of the church in promoting reconciliation in postTRC South Africa', in A. Chapman \& B. Sprong (eds.), Religion and reconciliation in South Africa, pp. 269-281, Templeton Foundation Press, Philadelphia, PA.

Van Wyk, M.M. \& Toale, M., 2015, 'Research design', in O. Chinedu \& M. Van Wyk (eds.), Educational research: An African approach, Oxford University Press, Cape Town.

Warren, R., 1995, The purpose driven church: Every church is big in God's eyes, Zondervan Press, MI.

Yale/Columbia Index, 2012, Center for Environmental Law and Policy, Yale University Center for International Earth Science Information Network, Columbia University. 